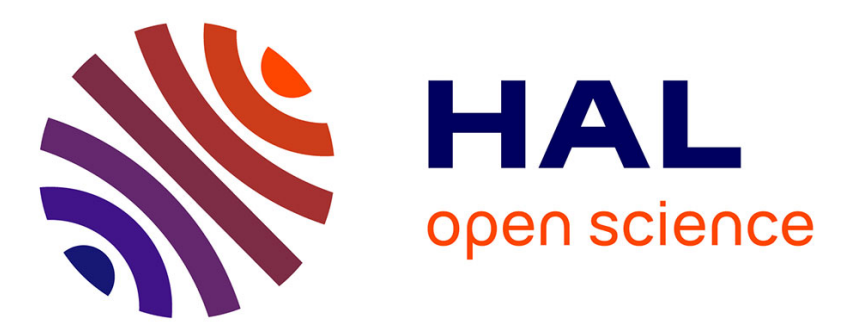

\title{
A Multi-leveled ANP-LCA Model for the Selection of Sustainable Design Options
}

\author{
Manel Sansa, Ahmed Badreddine, Taieb Ben Romdhane
}

\section{To cite this version:}

Manel Sansa, Ahmed Badreddine, Taieb Ben Romdhane. A Multi-leveled ANP-LCA Model for the Selection of Sustainable Design Options. 14th IFIP International Conference on Product Lifecycle Management (PLM), Jul 2017, Seville, Spain. pp.473-486, 10.1007/978-3-319-72905-3_42 . hal01764199

\section{HAL Id: hal-01764199 \\ https://hal.inria.fr/hal-01764199}

Submitted on 11 Apr 2018

HAL is a multi-disciplinary open access archive for the deposit and dissemination of scientific research documents, whether they are published or not. The documents may come from teaching and research institutions in France or abroad, or from public or private research centers.
L'archive ouverte pluridisciplinaire HAL, est destinée au dépôt et à la diffusion de documents scientifiques de niveau recherche, publiés ou non, émanant des établissements d'enseignement et de recherche français ou étrangers, des laboratoires publics ou privés. 


\title{
A multi-leveled ANP-LCA model for the selection of sustainable design options
}

\author{
Manel Sansa ${ }^{1}$, Ahmed Badreddine ${ }^{2}$, Taieb ben Romdhane ${ }^{1}$ \\ ${ }^{1}$ LISI, Institut National des sciences Appliquées et de Technologie, Université de Carthage, \\ Centre Urbain Nord BP 676, 1080, Tunisie. \\ ${ }^{2}$ LARODEC, Institut Supérieur de Gestion de Tunis, 41 Avenue de la liberté, 2000 Le Bardo, \\ Tunisie.

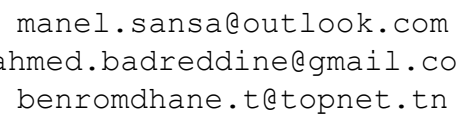

\begin{abstract}
The aim of this paper is to propose a new model for the selection of sustainable design options. This model is based on the environmental, the economic, and the social life cycle assessments. It deals with the uncertainties and the imprecisions due to the technological choices and their potential impacts since early design phase of the product. The proposed model is based on four principles, namely: Early integration, life cycle thinking, functionality thinking, and the multi-criteria concept. A case study is presented to validate the applicability of the proposed model on the design of batteries.
\end{abstract}

Keywords: Sustainable design, Eco-design, ELCA, EcLCA, SLCA, Fuzzy

ANP

\section{Introduction}

The sustainable development has become widely embraced by industries. It links the concept of sustainability to the social, economic and environmental challenges faced by humanity [1]. To this end, designers have to improve the reliability of the product since its design phase. Despite the acknowledgment of the sustainability approaches, its application has been limited to single aspects which the best known is the eco-designs approaches [2]. The implementation of the design strategies is not an easy task due to the lack of necessary roadmaps [3]. In this context, many tools are available, the most suitable ones are the Environmental Life Cycle Assessment (ELCA) [4], the Economic Life Cycle Assessment (EcLCA) [5], and the Social Life Cycle Assessment (SLCA) [6]. However, these methods are more complex at an early stage of the design phase since they require significant data through all the life cycle phases which leads to uncertain and imprecise results. To this end, we propose a new model which combines the eco-design strategies with the concept of sustainable development. This model aims to select the optimal sustainable design option for a product at an early stage using simplified ELCA, EcLCA and SLCA and the fuzzy ANP [7] [8] [9]. The remainder of 
this paper is laid out as follows: Section 2 presents the problem statement and the motivation. Section 3 describes and details the different steps of the proposed model. Section 4 presents the implementation of the model on a case study. Finally, section 5 concludes the research.

\section{Problem statement and motivation}

In the literature, several researches have been conducted on the sustainable design. Table 1 summarizes the most recent ones.

Table 1. The related works on sustainable design

\begin{tabular}{|c|c|c|c|c|c|c|c|c|}
\hline \multirow{2}{*}{$\begin{array}{l}\text { Existing } \\
\text { works }\end{array}$} & \multicolumn{3}{|c|}{ Sustainable design } & \multirow{2}{*}{$\begin{array}{l}\text { Early } \\
\text { integrati } \\
\text { on }\end{array}$} & \multirow{2}{*}{$\begin{array}{l}\text { Life } \\
\text { cycle } \\
\text { thinki } \\
\text { ng } \\
\end{array}$} & \multirow{2}{*}{$\begin{array}{l}\text { Functional } \\
\text { ity } \\
\text { thinking }\end{array}$} & \multirow{2}{*}{$\begin{array}{l}\text { Multi- } \\
\text { criteria } \\
\text { concept }\end{array}$} & \multirow{2}{*}{$\begin{array}{l}\text { Uncertaint } \\
\text { ies issues }\end{array}$} \\
\hline & $\mathrm{E}$ & $\mathrm{Ec}$ & $\mathrm{S}$ & & & & & \\
\hline $\begin{array}{l}\text { Romli et } \\
\text { al. [10] }\end{array}$ & $\mathrm{X}$ & N.A & N.A & $\begin{array}{l}\text { Design } \\
\text { process }\end{array}$ & $\begin{array}{l}\text { The } \\
\text { use of } \\
\text { LCA }\end{array}$ & $\begin{array}{l}\text { Quality } \\
\text { function } \\
\text { deploymen } \\
\mathrm{t} \text {, } \\
\text { functional } \\
\text { unit }\end{array}$ & $\begin{array}{l}\text { The use of } \\
\text { LCA }\end{array}$ & N.A \\
\hline $\begin{array}{l}\text { Wang et } \\
\text { al. [11] }\end{array}$ & $\mathrm{X}$ & N.A & N.A & $\begin{array}{l}\text { Design } \\
\text { process }\end{array}$ & $\begin{array}{l}\text { The } \\
\text { use of } \\
\text { LCA }\end{array}$ & $\begin{array}{l}\text { Functional } \\
\text { unit }\end{array}$ & $\begin{array}{l}\text { Criteria } \\
\text { defined for } \\
\text { each life } \\
\text { cycle phase }\end{array}$ & $\begin{array}{l}\text { Fuzzy } \\
\text { logic }\end{array}$ \\
\hline $\begin{array}{l}\mathrm{Ng} \text { and } \\
\text { Chuah } \\
{[12]}\end{array}$ & $\mathrm{X}$ & N.A & N.A & $\begin{array}{l}\text { Design } \\
\text { process }\end{array}$ & $\begin{array}{l}\text { The } \\
\text { use of } \\
\text { rough- } \\
\text { cut } \\
\text { LCA }\end{array}$ & $\begin{array}{l}\text { Functional } \\
\text { unit }\end{array}$ & AHP & $\begin{array}{l}\text { Fuzzy } \\
\text { logic, } \\
\text { Evidential } \\
\text { Reasoning }\end{array}$ \\
\hline $\begin{array}{l}\text { Fragnoli } \\
\text { et al. } \\
{[13]}\end{array}$ & $X$ & $\begin{array}{l}\text { Ergono } \\
\text { mic } \\
\text { issues }\end{array}$ & $\begin{array}{l}\text { Safety } \\
\text { issues }\end{array}$ & $\begin{array}{l}\text { Redesig } \\
\mathrm{n} \\
\text { process }\end{array}$ & N.A & $\begin{array}{l}\text { Function } \\
\text { analysis }\end{array}$ & $\begin{array}{l}\text { Environmen } \\
\text { tal, quality } \\
\text { and costs } \\
\text { indices }\end{array}$ & N.A \\
\hline $\begin{array}{l}\text { Bereketl } \\
\mathrm{i} \quad \text { and } \\
\text { Genevoi } \\
\mathrm{s}[14]\end{array}$ & $\mathrm{X}$ & $\mathrm{X}$ & $\mathrm{X}$ & $\begin{array}{l}\text { Design } \\
\text { process }\end{array}$ & N.A & QFDE & AHP & $\begin{array}{l}\text { Fuzzy } \\
\text { AHP }\end{array}$ \\
\hline $\begin{array}{l}\text { Younesi } \\
\text { and } \\
\text { Roghani } \\
\text { an [15] }\end{array}$ & $\mathrm{X}$ & $\mathrm{X}$ & $\begin{array}{l}\text { Produ } \\
\text { ct } \\
\text { qualit } \\
\text { y }\end{array}$ & $\begin{array}{l}\text { Design } \\
\text { process }\end{array}$ & N.A & QFDE & ANP & $\begin{array}{l}\text { Fuzzy } \\
\text { logic, } \\
\text { DEMATE } \\
\text { L }\end{array}$ \\
\hline
\end{tabular}


According to the related works and the international standards [2] [4] [16], the following principles are recommended for designers in order to achieve a sustainable design: (i) Early integration: The improvement of the environmental performance of the product must be considered at early stages of the design process because such improvement will be more difficult if the product is already developed. (ii) Life cycle thinking: The consideration of all the stages of the life cycle is necessary to better locate where and how the product can affect the environment, the economy and the society. (iii) Functionality thinking: The purpose and performance requirements of the products must be taken into account through the life cycle analysis. (iiii) Multicriteria concept: The combination between criteria such as environment, economy and society must be considered through the design process.

In addition, most of the related works (See Table 1) have ignored the economic and social aspects. Their proposed frameworks treated only the environmental issues. Moreover, these researchers pointed out the complexity of the complexity of the LCA method at the design phase which leads to uncertain results and unsuitable design decisions.

To overcome these weaknesses, our proposed model is based on simplified ELCA, EcLCA, and SLCA methods. The simplified life cycle assessment was proposed by $\mathrm{Ng}$ C.Y [17] as a rough-cut LCA in order to address the complexity of the full LCA and to obtain the environmental performance of the desired product with the available data. Then, our idea is to connect these results to a multi-leveled fuzzy Analytic Network Process [7] [8] [9] for decision support.

\section{A new model for the selection of sustainable design options}

The proposed model is outlined in Fig.1. The model selects the optimal sustainable design option for a specific product during its design phase taking into account its life cycle phases $\mathrm{LCP}_{\mathrm{j}}$ where $\mathrm{j}=[1 . .5], \mathrm{LCP}_{1}$ is the extraction of raw materials, $\mathrm{LCP}_{2}$ is the manufacturing, $\mathrm{LCP}_{3}$ is the distribution, $\mathrm{LCP}_{4}$ is the use and maintenance and $\mathrm{LCP}_{5}$ is the end of life. This model is based on an environmental, economic, and social life cycle assessments conducted on each option on the basis of a unique functional unit which is a quantified description of the main function of the product. The functional unit is considered as a mutual reference between the three life cycle assessments. The model is detailed as follows:

Let $\mathrm{PDO}_{\mathrm{i}}$ be the set of the product's design options where $\mathrm{i}=[1 . . \mathrm{n}]$ and $\mathrm{n}$ is the number of design options.

Let PDOs be the selected optimal sustainable design option.

- For each $\mathrm{PDO}_{\mathrm{i}}$, the environmental, economic, and social impacts are assessed on the basis of multi-criteria and life cycle approaches in order to evaluate the impacts through all the life cycle phases. The results of these assessments are a set of environmental indicators $\mathrm{EI}_{\mathrm{x}}$, economic indicators $\mathrm{ECI}_{\mathrm{y}}$ and social indicators $\mathrm{SL}_{\mathrm{Z}}$ where $\mathrm{x}, \mathrm{y}$ and $\mathrm{Z}$ are the numbers of the set of environmental, economic and social indicators. 
- For each life cycle phase $\mathrm{LCP}_{\mathrm{j}}$, the priority weights relative to each $\mathrm{PDO}_{\mathrm{i}}$ are computed through a multi-criteria decision-making system using the environment, the economy and the society as criteria, and the aforementioned indicators as the relative sub-criteria.

- For each $\mathrm{PDO}_{\mathrm{i}}$, the global score is computed on the basis of the calculated priority weights per life cycle phase, the PDOi with the highest score is the selected option PDOs.

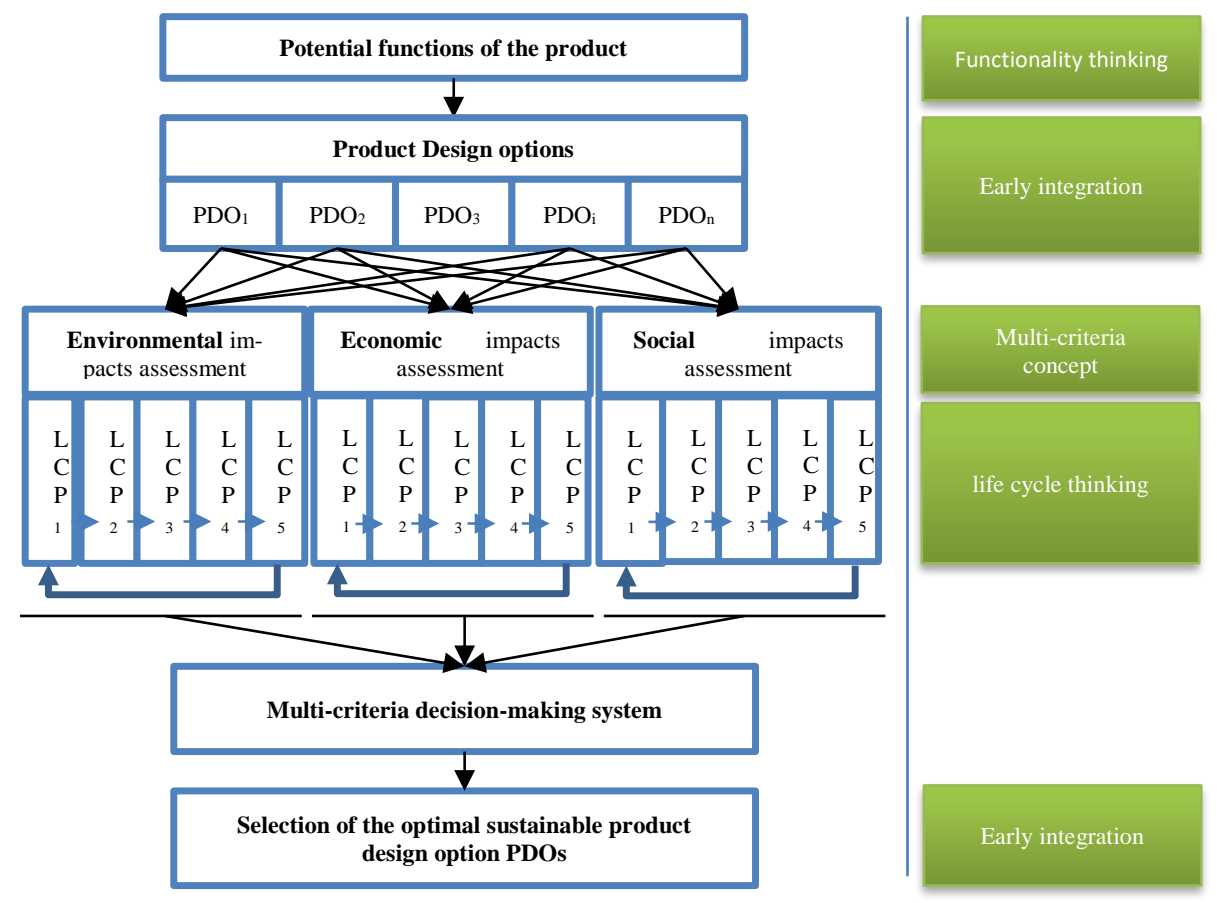

Fig. 1. Conceptual framework of the proposed model

\subsection{Impacts assessement}

\section{Environmental impacts assessment}

The potential environmental impacts of the product are assessed using the ELCA method taking into account all the phases of the life cycle [4]. It allows the definition of the environmental profile of the product for each $\mathrm{PDO}_{\mathrm{i}}$. this method consists of four main iterative steps: The first defines the goal and the scope of the study. The second determines the inventory of the elementary and intermediate flows related to the environment. The third is dedicated to the assessment of the environmental impacts related to the identified flows. In fact, these latter are classified and characterized by impacts and damage categories. At this stage, environmental databases such as the ecoinvent [18] and aggregation methods such as Impact 2002+ [19] are used. The choice of these methods depends on the environmental impacts categories and the consideration of time and space. The final step interprets the results of the studies compared to the identified 
objectives. In this model, we have chosen a simplified version of the full ELCA [17]. In fact, the product is not manufactured yet. Thus, the inventory data are estimated on the basis of the $\mathrm{PDO}_{\mathrm{i}}$. Environmental indicators $\mathrm{EI}_{\mathrm{x}}$ of impacts categories are resulted from the life cycle impacts assessment.

\section{Economic impacts assessment}

The economic impacts assessment has been proposed by Neugebauer et al. [5]. The EcLCA proposes characterization tools considering economic midpoint categories and endpoint damage categories. It is the most suitable version since it is compatible with the ELCA structure. The assessment of the economic impacts results indicators ECI $_{\mathrm{y}}$ relative to each life cycle phase.

\section{Social impacts assessment}

The SLCA [6] analyzes the social impacts of the product through its life cycle phases following the same steps of the ELCA. The social impacts relative to each $\mathrm{PDO}_{\mathrm{i}}$ may affect the stakeholders (e.g. the employees, the society, the consumers) positively and negatively. In addition, many impacts categories are identified such as the safety and the human rights. As described in the ELCA, there are databases, classification and characterization methods in order to calculate the social indicators $\mathrm{SI}_{\mathrm{z}}$.

\subsection{Selection of the optimal sustainable design option}

At this stage, on the basis of the indicators computed above, the optimal sustainable product design option $\mathrm{PDO}_{\mathrm{S}}$ is selected using the fuzzy ANP [9]. The choice of this method is due to the dependency among the three aspects and the uncertainty and imprecision of the ELCA, EcLCA, and SLCA results and the judgments of the decisionmakers. The fuzzy ANP considers triangular fuzzy numbers denoted 1, m, and u where 1 is the smallest possible value, $m$ is the most promising value and $u$ is the largest possible value. These parameters describe a fuzzy event and their relative membership function is defined below [20]:

$$
\mu(x)=\left\{\begin{array}{l}
\frac{x-l}{m-l} \text { if } l \leq x \leq m \\
\frac{u-x}{u-m} \text { if } m \leq x \leq u \\
0 \quad \text { Otherwise }
\end{array}\right.
$$

Therefore, the fuzzy pair-wise comparison matrix $\widetilde{M}$ is presented below: 


$$
\tilde{M}=\left(\begin{array}{cccc}
(1,1,1) & \left(E_{12}^{l}, E_{12}^{m}, E_{12}^{u}\right) & \cdots & \left(E_{1 n}^{l}, E_{1 n}, E_{1 n}^{u}\right) \\
\left(\frac{1}{E_{12}^{u}}, \frac{1}{E_{12}^{m}}, \frac{1}{E_{12}^{l}}\right) & (1,1,1) & \cdots & \left(E_{2 n}^{l}, E_{2 n}^{m}, E_{2 n}^{u}\right) \\
\vdots & \vdots & \ddots & \vdots \\
\left(\frac{1}{E_{1 n}^{u}}, \frac{1}{E_{1 n}^{m}}, \frac{1}{E_{1 n}^{l}}\right) & \left(\frac{1}{E_{2 n}^{u}}, \frac{1}{E_{2 n}^{m}}, \frac{1}{E_{2 n}^{l}}\right) & \cdots & (1,1,1)
\end{array}\right)
$$

Where $E_{i j}^{l, m, u}=\left(E_{i j}^{l}, E_{i j}^{m}, E_{i j}^{u}\right)$ and $E_{j i}^{l, m, u}=\left(\frac{1}{E_{i j}^{u}}, \frac{1}{E_{i j}^{m}}, \frac{1}{E_{i j}^{l}}\right)$ are the fuzzy preference which compare the $\mathrm{i}^{\text {th }}$ with the $\mathrm{j}^{\text {th }}$ element where $\mathrm{i}($ resp.j) $=[1 . . \mathrm{n}]$ is the number of rows (resp. columns) of the matrix $\breve{M}$. The weights relative to each element k of the matrix $\widetilde{M}$ where $\mathrm{k}=[1 . . \mathrm{n}]$ and $\mathrm{n}$ is the number of the elements, are computed as follows: Let $W_{k}^{l, m, u}=\left(W_{k}^{l}, W_{k}^{m}, W_{k}^{u}\right)$ be the triangular fuzzy weight relative to the $\mathrm{k}^{\text {th }}$ element of the matrix $\bar{M} . W_{k}^{l, m, u}$ is computed using the logarithmic least squares method given in equation (3) [20].

$$
W_{k}^{l, m, u}=\frac{\left(\prod_{j=1}^{n} E_{k j}^{l, m, u}\right)^{1 / n}}{\sum_{i=1}^{n}\left(\Pi_{j=1}^{n} E_{i j}^{l, m, u}\right)^{1 / n}}
$$

Since the ANP method is applied for each life cycle phase, we suggest the multileveled fuzzy ANP. The criteria relative to our model are: The environment $(\mathrm{E})$, the economy (Ec), and the society $(\mathrm{S})$. the sub-criteria are: $\mathrm{EI}_{\mathrm{x}}, \mathrm{ECI}_{\mathrm{y}}, \mathrm{SI}_{\mathrm{z}}$. The alternatives are: The product design options $\mathrm{PDO}_{\mathrm{i}}$. We note that all the fuzzy pair-wise comparison matrices are determined using (2) and all the fuzzy weights are computed using (3). The steps to conduct the fuzzy ANP relative to the proposed model are outlined below: Let $W_{I C}^{l, m, u}$ (resp. $W_{D C}^{l, m, u}, W_{S C}^{l, m, u}, W_{A}^{l, m, u}$ ) be the set of weights relative to independent (resp. dependent criteria, sub-criteria, alternatives).

Let $W_{C}^{l, m, u}$ (resp. $W_{O P}^{l, m, u}, W_{G P}^{l, m, u}$ ) be the set of overall priority weights relative to criteria (resp. sub-criteria, alternatives).

Let $G S_{i}$ be the global score of each $\mathrm{PDO}_{\mathrm{i}}$.

1. Determine the comparison matrix between each criterion by supposing that they are independent and compute $W_{I C}^{l, m, u}$.

2. Determine the comparison matrix between each criterion by considering the dependency among them and compute $W_{D C}^{l, m, u}$.

3. Compute $W_{C}^{l, m, u}$ by multiplying $W_{I C}^{l, m, u}$ and $W_{D C}^{l, m, u}$.

4. Determine the comparison matrix between the sub-criteria with respect to the criteria and compute $W_{S C}^{l, m, u}$.

5. Compute $W_{O P}^{l, m, u}$ by multiplying $W_{C}^{l, m, u}$ and $W_{S C}^{l, m, u}$ for each sub-criterion.

6 . For each $\mathrm{LCP}_{\mathrm{j}}$, determine the comparison matrix between the alternatives with respect to each sub-criterion. 
7. Compute $W_{A}^{l, m, u}$ and then $W_{G P}^{l, m, u}$ for each alternative by multiplying $W_{A}^{l, m, u}$ and $W_{O P}^{l, m, u}$

Once $W_{G P}^{l, m, u}$ are computed for all the life cycle phases, the last step is to compute the $G S_{i}$ for each $\mathrm{PDO}_{\mathrm{i}}$ by summing the $W_{G P}$ of each life cycle phase.

\section{Case study}

In order to illustrate the proposed model, we present its application within a company that designs and manufactures electronic products for a specific usage. Designers have chosen to apply the proposed model for the selection of the optimal battery technology with the aim to design a sustainable product.

\subsection{Identifying the PDO $_{\mathrm{i}}$}

To simplify the application of the proposed model, only four batteries technologies noted as design options $\mathrm{PDO}_{1}, \mathrm{PDO}_{2}, \mathrm{PDO}_{3}$, and $\mathrm{PDO}_{4}$ are defined in Table 2 in order to select the most sustainable one.

Table 2. The types and properties relative to each $\mathrm{PDO}_{\mathrm{i}}$

\begin{tabular}{|l|l|l|l|l|}
\hline $\mathrm{PDO}_{\mathrm{i}}$ & $\begin{array}{l}\text { Type of chem- } \\
\text { istry cell }\end{array}$ & $\begin{array}{l}\text { Nominal volt- } \\
\text { age (V) }\end{array}$ & $\begin{array}{l}\text { Cycle durabil- } \\
\text { ity (cycles) }\end{array}$ & $\begin{array}{l}\text { Specific en- } \\
\text { ergy (Wh/kg) }\end{array}$ \\
\cline { 3 - 5 } & $\begin{array}{l}\text { Lithium iron } \\
\text { phosphate }\end{array}$ & 2 & $1000-2000$ & $90-120$ \\
\hline $\mathrm{PDO}_{2}$ & $\begin{array}{l}\text { Lithium } \\
\text { nickel cobalt } \\
\text { aluminum ox- } \\
\text { ide }\end{array}$ & 3 & $1000-1500$ & $200-260$ \\
\hline $\mathrm{PDO}_{3}$ & $\begin{array}{l}\text { Lithium man- } \\
\text { ganese oxide }\end{array}$ & 2.5 & $300-700$ & $100-150$ \\
\hline $\mathrm{PDO}_{4}$ & $\begin{array}{l}\text { Lithium co- } \\
\text { balt oxide }\end{array}$ & 205 & $500-1000$ & $150-200$ \\
\hline
\end{tabular}

- $\mathrm{PDO}_{1}$ : Lithium iron phosphate (LiFePO4). This option consists of a graphite carbon anode and an iron phosphate cathode. It is characterized by a lower specific energy, a longer life span and a better specific power than the other lithium ions batteries. $\mathrm{PDO}_{1}$ offers good safety characteristics regarding the users and manufacturers consider it as a potential replacement for the common lead acid batteries. The materials have low costs and do not harm the environment compared to the other options [21].

- $\mathrm{PDO}_{2}$ : Lithium nickel cobalt aluminum oxide ( $\mathrm{LiNiCoAlO}_{2}$ ). This battery consists of a graphite carbon anode and a nickel cobalt aluminum oxide. The aluminum 
offers specific energy and power and a long-life span. However, the costs relative to this option are high and the percentage of its safety is very low [22].

- $\mathrm{PDO}_{3}$ : Lithium manganese oxide $\left(\mathrm{LiMn}_{2} \mathrm{O}_{4}\right)$. This option consists of a graphite carbon anode and a manganese oxide cathode. It is considered safer than lithium cobalt in terms of overheating risks and also less expensive. PDO3 is known for its high power but less capacity and a short life span. In addition, it is composed of nontoxic material which does not treat the environment and the human being [23].

- $\mathrm{PDO}_{4}$ : Lithium cobalt oxide $\left(\mathrm{LiCoO}_{2}\right)$. This battery is composed of a graphite carbon anode and a cobalt oxide cathode. It is characterized by its high specific energy which has increased its market share. However, the cobalt material is known for its high costs. Besides, $\mathrm{PDO}_{4}$ has a short life span and a low thermal stability compared to the remaining options. Regarding the environment and the society, this battery contains material with very low percentage of toxicity but these materials may harm the environment and the human-being in case of improper disposal at the end of life [21].

\subsection{Conducting a life cycle assessment}

For each $\mathrm{PDO}_{\mathrm{i}}$, simplified EcLCA, and SLCA methods have been conducted using the Quantis software and the Ecoinvent 2.2 database [18]. The three assessments are based on a unique functional unit which is the use of the battery for five years. All the collected data are normalized to the functional unit and then treated in order to evaluate the potential impacts. At this stage, the IMPACT 2002+ method [19] has been chosen. For simplicity reasons, the endpoint indicators are computed and taken into account in the case study.

\section{Environmental assessment}

As shown in Fig.2, four impacts indicators, namely; $\mathrm{EI}_{1}$ : human health, $\mathrm{EI}_{2}$ : ecosystem quality, $\mathrm{EI}_{3}$ : climate change, and $\mathrm{EI}_{4}$ : resources are computed for each $\mathrm{PDO}_{\mathrm{i}}$ through all the life cycle phases. We can remark that all $\mathrm{PDO}_{\mathrm{i}}$ have approximately the same impacts on the human health in $\mathrm{LCP}_{1}(\approx 22 \%)$. In fact, all options are lithium based and this element is extracted through lithium mining. This process is considered harmful for the environment. Besides, the exposure of workers to the lithium dust for a long period causes respiratory problems and air pollution. In addition, $\mathrm{PDO}_{1}$ and $\mathrm{PDO}_{3}$ have the same impacts in $\mathrm{LCP}_{4}(\approx 28 \%)$ regarding the climate change due to the carbon emissions when charging the batteries. Moreover, $\mathrm{PDO}_{1}$ has greater impact on the climate change in $\mathrm{LCP}_{2}(\approx 28 \%)$ and LCP5 $(\approx 24 \%)$ because it generates more carbon dioxide during these phases compared to the other $\mathrm{PDO}_{\mathrm{i}}$. Also, we can remark that $\mathrm{PDO}_{2}$ has a significant impact on the ecosystem quality $(\approx 25 \%)$ and the human health $(\approx 24 \%)$ especially in $\mathrm{LCP}_{2}$ and $\mathrm{LCP}_{5}$ because the aluminum is considered as a toxic metal and it has significant effects on the aquatic and terrestrial ecosystems due to the emission of this metal during the manufacturing phase and its disposal at the end of life phase. $\mathrm{PDO}_{1}$ and $\mathrm{PDO}_{3}$ have lower impacts on the human health $(\approx 23 \%)$ in $\mathrm{LCP}_{5}$ than 
$\mathrm{PDO}_{2}$ and $\mathrm{PDO}_{4}(\approx 25 \%)$. In fact, manganese and iron have lower toxicity percentage whereas nickel and cobalt belong to the hazardous material category. Finally, we can remark that all $\mathrm{PDO}_{\mathrm{i}}$ have approximately the same impacts on $\mathrm{LCP}_{3}$ due to the assumptions that the distribution phase is similar for all options regarding the distance and the fuel consumption and emissions (i.e. $\mathrm{EI}_{1} \approx 24 \%, \mathrm{EI}_{2} \approx 25 \%, \mathrm{EI}_{3} \approx 25 \%, \mathrm{EI}_{4} \approx 26 \%$ ).

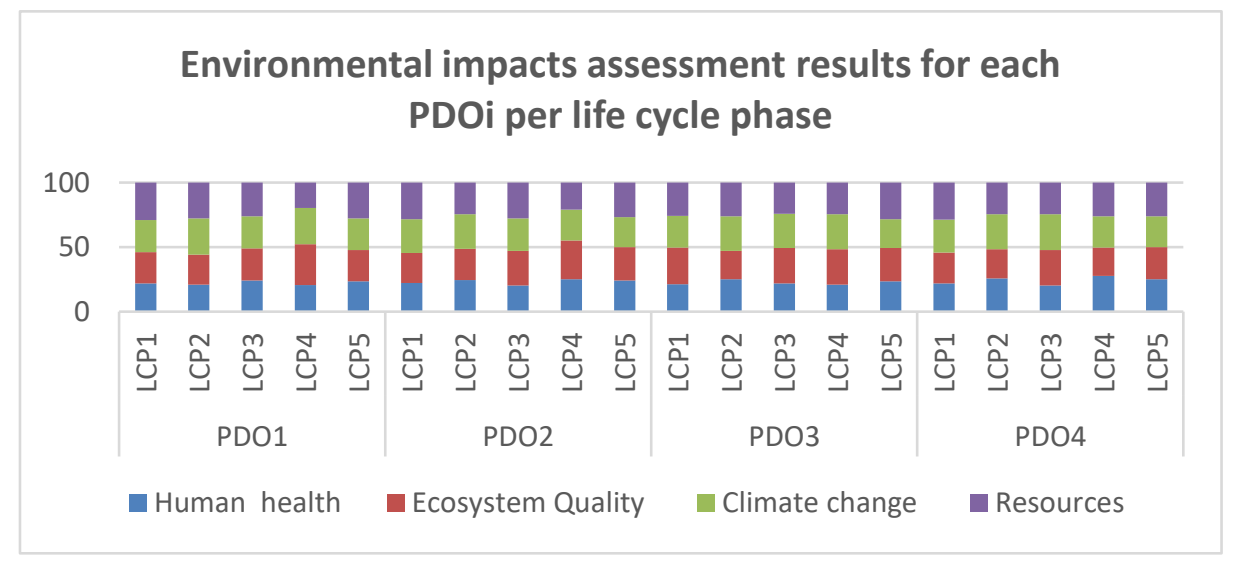

Fig. 2. Results of the ELCA impacts assessment

\section{Economic assessment}

Two indicators are computed from the impacts assessment of the EcLCA as illustrated in Fig.3: $\mathrm{ECI}_{1}$ : economic prosperity and $\mathrm{ECI}_{2}$ : economic resilience. $\mathrm{ECI}_{1}$ is estimated through the profitability, productivity of the organization and the consumer satisfaction deduced from the market share of the product. $\mathrm{ECI}_{2}$ expresses the ability to prevent changes without drawbacks for the economic stability [5]. We can note from Fig. 3 that $\mathrm{PDO}_{2}$ and $\mathrm{PDO}_{4}$ have the highest impact on the economic prosperity due to the high costs of the raw materials $(\approx 50 \%)$, manufacturing $(\approx 40 \%)$, and the end of life treatments, and the end of life treatments $(\approx 28 \%)$. In addition, $\mathrm{PDO}_{1}$ and $\mathrm{PDO}_{3}$ have the highest impact on the economic resilience especially during $\mathrm{LCP}_{4}(\approx 65 \%)$ since the level of competitiveness on the market has increased due to investments on improving the nickel metal hybrid and the absorbed glass mat batteries that are characterized by their low costs, safer for the environment, and affordable by the consumer.

\section{Social assessment}

The impacts assessment relative to the SLCA results an indicator that estimates the well-being of stakeholders $\mathrm{SI}_{1}$ (See Fig.4). In this context, the stakeholders are all human-being that are involved within the product (i.e. employees, consumers, managers, governors). 


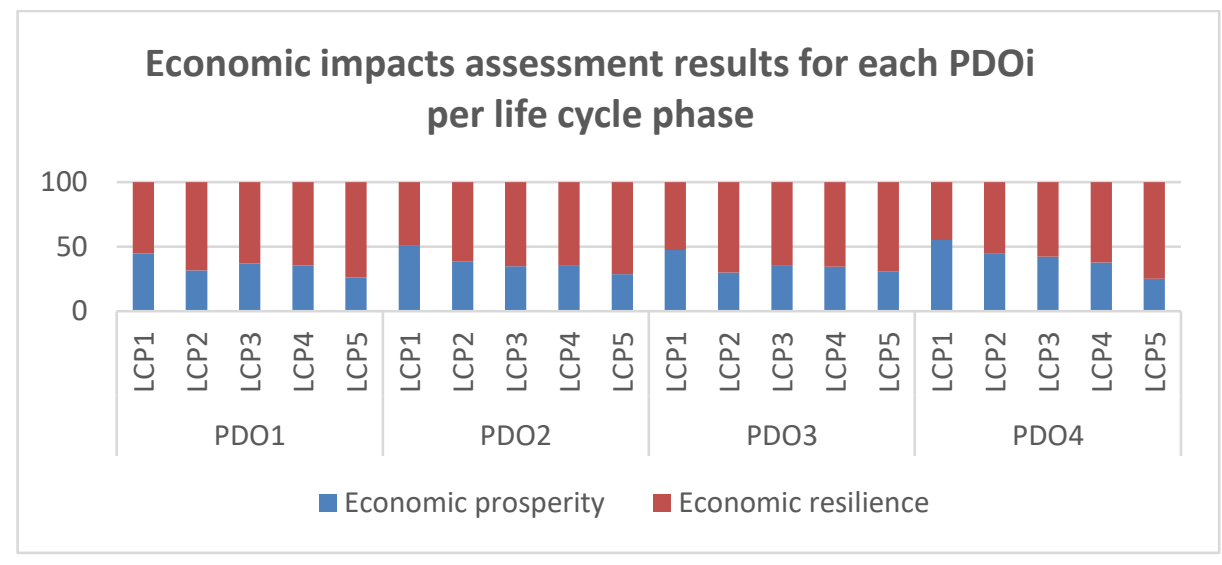

Fig. 3. Results of the EcLCA impacts assessment

As shown in Fig.4. we can remark that $\mathrm{PDO}_{2}$ and $\mathrm{PDO}_{4}$ have significant impacts on the human well-being particularly during $\mathrm{LCP}_{2}(\approx 26 \%)$ and $\mathrm{LCP}_{4}(\approx 28 \%)$. In fact, the workers are exposed to hazard materials as well as the consumers. $\mathrm{PDO}_{1}$ and $\mathrm{PDO}_{3}$ have the lowest impacts on all phases since they offer good safety characteristics and consist of non-toxic materials.

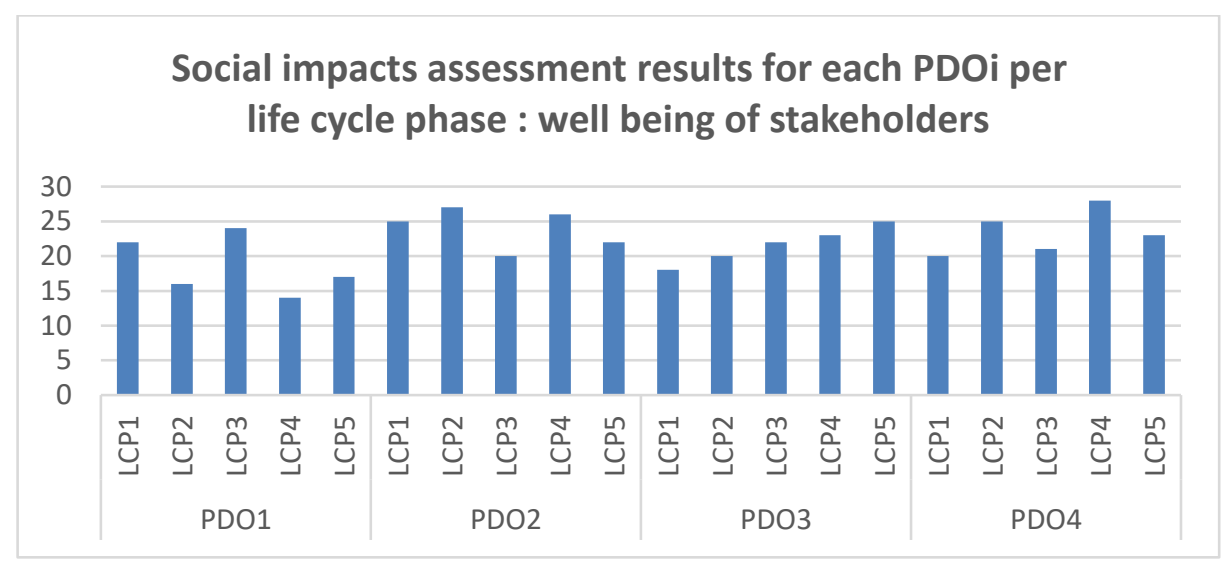

Fig. 4. Results of the SLCA impacts assessment

\subsection{Selecting the optimal sustainable design option}

Following the steps of the fuzzy ANP, the first step is to set the main comparison matrix $\breve{M}$ for the criteria E, Ec, and S using (2) with respect to the goal which is the selection of $\mathrm{PDO}_{\mathrm{s}}$. Supposing that the criteria are independent, the comparison is based on a judgment scale predefined using (1) [9]. $\breve{M}$ is defined on the basis of the judgments 
of the designers taking into account the properties of the different $\mathrm{PDO}_{\mathrm{i}}$ and obtained as follows:

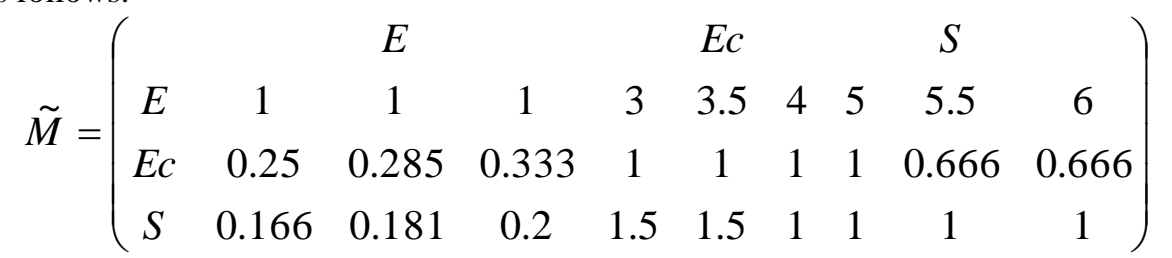

For example, the Environment (E) is moderately to strongly preferred than the Economy (Ec) with respect to the goal. Then, considering the dependencies between the criteria, we set the matrix $\breve{M}_{\text {inter-dependencies }}$ by comparing the criteria with respect to each other's. For instance, we compare $\mathrm{Ec}$ and $\mathrm{S}$ with respect to $\mathrm{E}$. $\bar{M}_{\text {inter-dependencies }}$ is obtained as follows:

$$
\tilde{M}_{\text {inter-dependencies }}=\left(\begin{array}{ccccccccccc} 
& \multicolumn{4}{c}{E} & \multicolumn{4}{c}{E c} & & \\
E & 1 & 1 & 1 & 0.449 & 0.4 & 0.449 & 0.5 & 0.5 & 0.5 \\
E c & 0.224 & 0.222 & 0.224 & 1 & 1 & 1 & 0.5 & 0.5 & 0.5 \\
S & 0.775 & 0.777 & 0.775 & 0.55 & 1.6 & 0.55 & 1 & 1 & 1
\end{array}\right)
$$

Then, we obtain two comparison matrices for the sub-criteria $\mathrm{EI}_{\mathrm{x}}, \mathrm{ECI}_{\mathrm{y}}$ with respect to $\mathrm{E}$ and Ec respectively. Since we have one social sub-criteria, the relative weight is equal to 1 . We present in Table 3 all the weights relative to $\mathrm{E}, \mathrm{Ec}, \mathrm{S}, \mathrm{EI}_{\mathrm{x}}, \mathrm{EI}_{\mathrm{y}}, \mathrm{SI}_{\mathrm{z}}$ computed using (3).

\begin{tabular}{|c|c|c|c|c|c|c|c|c|c|c|}
\hline \multirow[t]{2}{*}{ Criteria } & \multicolumn{3}{|l|}{$\mathrm{w}_{\mathrm{C}}$} & \multirow{2}{*}{$\begin{array}{l}\text { Sub } \\
\text { criteria }\end{array}$} & \multicolumn{3}{|l|}{$\mathrm{W}_{\mathrm{SC}}$} & \multicolumn{3}{|l|}{$\mathrm{W}_{\mathrm{OP}}$} \\
\hline & 1 & $\mathrm{~m}$ & $\mathrm{u}$ & & 1 & $\mathrm{~m}$ & $\mathrm{u}$ & 1 & $\mathrm{~m}$ & $\mathrm{u}$ \\
\hline \multirow[t]{4}{*}{ E } & \multirow[t]{4}{*}{0.3277} & \multirow[t]{4}{*}{0.3281} & \multirow[t]{4}{*}{0.328} & $\mathrm{EI}_{1}$ & 0.3096 & 0.3241 & 0.3489 & 0.1014 & 0.1063 & 0.1144 \\
\hline & & & & $\mathrm{EI}_{2}$ & 0.2603 & 0.2623 & 0.2467 & 0.0853 & 0.0861 & 0.0809 \\
\hline & & & & $\mathrm{EI}_{3}$ & 0.1503 & 0.1316 & 0.1576 & 0.0492 & 0.0431 & 0.0517 \\
\hline & & & & $\mathrm{EI}_{4}$ & 0.2797 & 0.2818 & 0.2467 & 0.0917 & 0.0924 & 0.0809 \\
\hline \multirow[t]{2}{*}{$\mathrm{Ec}$} & \multirow[t]{2}{*}{0.2614} & \multirow[t]{2}{*}{0.2614} & \multirow[t]{2}{*}{0.2614} & $\mathrm{ECI}_{1}$ & 0.25 & 0.2222 & 0.2 & 0.0653 & 0.0581 & 0.0522 \\
\hline & & & & $\mathrm{ECI}_{2}$ & 0.75 & 0.7777 & 0.8 & 0.1961 & 0.2033 & 0.2091 \\
\hline $\mathrm{S}$ & 0.4107 & 0.4104 & 0.4104 & $\mathrm{SI}_{1}$ & 1 & 1 & 1 & 0.4107 & 0.4104 & 0.4104 \\
\hline
\end{tabular}

Table 3. The overall priority weights relative to the criteria and the sub-criteria per $\mathrm{LCP}_{1}$

At this stage, for each $\mathrm{LCP}_{\mathrm{j}}$, seven comparison matrices for $\mathrm{PDO}_{i}$ with respect to $\mathrm{EI}_{\mathrm{x}}, \mathrm{EI}_{\mathrm{y}}$, and $\mathrm{SI}_{\mathrm{z}}$ are identified from the judgments of designers on the basis of the impacts assessments results shown in Fig.2, Fig.3, and Fig.4. since the same step is performed for each $\mathrm{LCP}_{\mathrm{j}}$, we present the results of the application of the fuzzy ANP for $\mathrm{LCP}_{1}$. The seven comparison matrices for the $\mathrm{PDO}_{\mathrm{i}}$ with respect to $\mathrm{EI}_{\mathrm{x}}, \mathrm{EI}_{\mathrm{y}}$ and $\mathrm{SI}_{\mathrm{z}}$ are detailed in Table 4. The following step is to determine the priority weights relative to each $\mathrm{PDO}_{\mathrm{i}}$ for $\mathrm{LCP}_{1}$ as presented in Table 5. Then, $\mathrm{W}_{\mathrm{GP}}$ is obtained by multiplying $W_{A}^{l, m, u}$ and $W_{O P}^{l, m, u}$. 
Table 4. The comparison matrices relative to $\mathrm{PDO}_{\mathrm{i}}$ with respect to $\mathrm{EI}_{\mathrm{x}}, \mathrm{EI}_{\mathrm{y}}$ and $\mathrm{SI}_{\mathrm{z}}$ for $\mathrm{LCP}_{1}$.

\begin{tabular}{|c|c|c|c|c|c|c|c|c|c|c|c|c|}
\hline & \multicolumn{3}{|c|}{$\mathrm{PDO}_{1}$} & \multicolumn{3}{|c|}{$\mathrm{PDO}_{2}$} & \multicolumn{3}{|c|}{$\mathrm{PDO}_{3}$} & \multicolumn{3}{|c|}{$\mathrm{PDO}_{4}$} \\
\hline & 1 & $\mathrm{~m}$ & $\mathrm{u}$ & 1 & $\mathrm{~m}$ & $\mathrm{u}$ & 1 & $\mathrm{~m}$ & $\mathrm{u}$ & 1 & $\mathrm{~m}$ & $\mathrm{u}$ \\
\hline \multicolumn{13}{|l|}{$\mathrm{EI}_{1}$} \\
\hline $\mathrm{PDO}_{1}$ & 1 & 1 & 1 & 1 & 1.5 & 1.5 & 1 & 0.5 & 0.5 & 1 & 1.5 & 1.5 \\
\hline $\mathrm{PDO}_{2}$ & 0.666 & 0.666 & 1 & 1 & 1 & 1 & 0.333 & 0.285 & 0.25 & 1 & 0.666 & 0.666 \\
\hline $\mathrm{PDO}_{3}$ & 2 & 2 & 1 & 4 & 3.5 & 3 & 1 & 1 & 1 & 1 & 2 & 2 \\
\hline $\mathrm{PDO}_{4}$ & 0.666 & 0.666 & 1 & 1.5 & 1.5 & 1 & 0.5 & 0.5 & 1 & 1 & 1 & 1 \\
\hline \multicolumn{13}{|l|}{$\mathrm{EI}_{2}$} \\
\hline $\mathrm{PDO}_{1}$ & 1 & 1 & 1 & 1 & 2 & 2 & 3 & 4 & 4.5 & 1 & 2 & 2 \\
\hline $\mathrm{PDO}_{2}$ & 0.5 & 0.5 & 1 & 1 & 1 & 1 & 0.333 & 0.285 & 0.25 & 1 & 0.666 & 0.666 \\
\hline $\mathrm{PDO}_{3}$ & 0.222 & 0.25 & 0.333 & 0.2 & 0.222 & 0.333 & 1 & 1 & 1 & 0.2 & 0.181 & 0.166 \\
\hline $\mathrm{PDO}_{4}$ & 0.5 & 0.5 & 1 & 0.666 & 0.666 & 1 & 6 & 5.5 & 5 & 1 & 1 & 1 \\
\hline \multicolumn{13}{|l|}{$\mathrm{EI}_{3}$} \\
\hline $\mathrm{PDO}_{1}$ & 1 & 1 & 1 & 1 & 2 & 2 & 0.333 & 0.285 & 0.25 & 1 & 1.5 & 1.5 \\
\hline $\mathrm{PDO}_{2}$ & 0.5 & 0.5 & 1 & 1 & 1 & 1 & 0.333 & 0.25 & 0.222 & 1 & 0.5 & 0.5 \\
\hline $\mathrm{PDO}_{3}$ & 4 & 3.5 & 3 & 4.5 & 4 & 3 & 1 & 1 & 1 & 3 & 3.5 & 4 \\
\hline $\mathrm{PDO}_{4}$ & 0.666 & 0.666 & 1 & 2 & 2 & 1 & 0.25 & 0.285 & 0.333 & 1 & 1 & 1 \\
\hline \multicolumn{13}{|l|}{$\mathrm{EI}_{4}$} \\
\hline $\mathrm{PDO}_{1}$ & 1 & 1 & 1 & 1 & 0.5 & 0.5 & 0.333 & 0.222 & 0.2 & 1 & 0.5 & 0.5 \\
\hline $\mathrm{PDO}_{2}$ & 2 & 2 & 1 & 1 & 1 & 1 & 0.2 & 0.181 & 0.166 & 1 & 1.5 & 1.5 \\
\hline $\mathrm{PDO}_{3}$ & 5 & 4.5 & 3 & 6 & 5.5 & 5 & 1 & 1 & 1 & 5 & 5.5 & 6 \\
\hline $\mathrm{PDO}_{4}$ & 2 & 2 & 1 & 0.666 & 0.666 & 1 & 0.166 & 0.181 & 0.2 & 1 & 1 & 1 \\
\hline \multicolumn{13}{|l|}{$\mathrm{ECI}_{1}$} \\
\hline $\mathrm{PDO}_{1}$ & 1 & 1 & 1 & 5 & 5.5 & 6 & 3 & 4 & 4.5 & 5 & 7 & 9 \\
\hline $\mathrm{PDO}_{2}$ & 0.166 & 0.181 & 0.2 & 1 & 1 & 1 & 0.333 & 0.222 & 0.2 & 3 & 4.5 & 5 \\
\hline $\mathrm{PDO}_{3}$ & 0.222 & 0.25 & 0.333 & 5 & 4.5 & 3 & 1 & 1 & 1 & 5 & 6 & 7 \\
\hline $\mathrm{PDO}_{4}$ & 0.111 & 0.142 & 0.2 & 0.2 & 0.222 & 0.333 & 0.142 & 0.166 & 0.2 & 1 & 1 & 1 \\
\hline \multicolumn{13}{|l|}{$\mathrm{ECI}_{2}$} \\
\hline $\mathrm{PDO}_{1}$ & 1 & 1 & 1 & 0.2 & 0.181 & 0.166 & 0.333 & 0.25 & 0.22 & 0.2 & 0.142 & 0.111 \\
\hline $\mathrm{PDO}_{2}$ & 6 & 5.5 & 5 & 1 & 1 & 1 & 3 & 4.5 & 5 & 0.333 & 0.222 & 0.2 \\
\hline $\mathrm{PDO}_{3}$ & 4.5 & 4 & 3 & 0.2 & 0.222 & 0.333 & 1 & 1 & 1 & 0.2 & 0.166 & 0.142 \\
\hline $\mathrm{PDO}_{4}$ & 9 & 7 & 5 & 5 & 4.5 & 3 & 7 & 6 & 5 & 1 & 1 & 1 \\
\hline \multicolumn{13}{|l|}{$\mathrm{SI}_{1}$} \\
\hline $\mathrm{PDO}_{1}$ & 1 & 1 & 1 & 3 & 4.5 & 5 & 0.2 & 0.181 & 0.166 & 0.333 & 0.285 & 0.25 \\
\hline $\mathrm{PDO}_{2}$ & 0.2 & 0.222 & 0.333 & 1 & 1 & 1 & 0.2 & 0.166 & 0.142 & 0.333 & 0.222 & 0.2 \\
\hline $\mathrm{PDO}_{3}$ & 6 & 5.5 & 5 & 7 & 6 & 5 & 1 & 1 & 1 & 0.333 & 0.285 & 0.25 \\
\hline $\mathrm{PDO}_{4}$ & 4 & 3.5 & 3 & 5 & 4.5 & 3 & 4 & 3.5 & 3 & 1 & 1 & 1 \\
\hline
\end{tabular}

Finally, the global score GS of each PDOi is computed by summing the $\mathrm{W}_{\mathrm{GP}}$ of the $\mathrm{PDO}_{\mathrm{i}}$ per life cycle phase. $\mathrm{W}_{\mathrm{GP}}$ and GS are presented in Table 6. 
Table 5. The priority weights relative to $\mathrm{PDO}_{i}$ with respect to $\mathrm{EI}_{\mathrm{x}}, \mathrm{ECI}_{\mathrm{y}}, \mathrm{SI}_{\mathrm{z}}$, for $\mathrm{LCP}_{1}$

\begin{tabular}{|l|l|l|l|l|l|l|l|}
\hline \multirow{2}{*}{$\mathrm{PDO}_{\mathrm{i}}$} & \multicolumn{7}{|c|}{$\mathrm{W}_{\mathrm{A}}$} \\
\cline { 2 - 8 } & $\mathrm{EI}_{1}$ & $\mathrm{EI}_{2}$ & $\mathrm{EI}_{3}$ & $\mathrm{EI}_{4}$ & $\mathrm{ECI}_{1}$ & $\mathrm{ECI}_{2}$ & $\mathrm{SI}_{1}$ \\
\hline \multicolumn{7}{|l|}{$W_{A}^{l}$} \\
\hline $\mathrm{PDO}_{1}$ & 0.2375 & 0.3358 & 0.156 & 0.1323 & 0.5496 & 0.0502 & 0.1127 \\
\hline $\mathrm{PDO}_{2}$ & 0.1631 & 0.2823 & 0.1312 & 0.1385 & 0.1193 & 0.2312 & 0.0572 \\
\hline $\mathrm{PDO}_{4}$ & 0.3995 & 0.0783 & 0.5567 & 0.6095 & 0.2867 & 0.0962 & 0.326 \\
\hline \multicolumn{7}{|c|}{$W_{A}^{m}$} \\
\hline $\mathrm{PDO}_{1}$ & 0.2339 & 0.4135 & 0.1966 & 0.0888 & 0.5815 & 0.0462 & 0.127 \\
\hline $\mathrm{PDO}_{2}$ & 0.1356 & 0.2802 & 0.1021 & 0.1573 & 0.1078 & 0.2492 & 0.055 \\
\hline $\mathrm{PDO}_{3}$ & 0.4394 & 0.0655 & 0.5406 & 0.6253 & 0.2661 & 0.1009 & 0.3201 \\
\hline $\mathrm{PDO}_{4}$ & 0.191 & 0.2406 & 0.1605 & 0.1284 & 0.0445 & 0.6035 & 0.4978 \\
\hline \multicolumn{7}{|c|}{$W_{A}^{u}$} \\
\hline $\mathrm{PDO}_{1}$ & 0.2432 & 0.3692 & 0.1972 & 0.0959 & 0.5997 & 0.04773 & 0.1393 \\
\hline $\mathrm{PDO}_{2}$ & 0.1509 & 0.2966 & 0.1223 & 0.1434 & 0.1015 & 0.2818 & 0.0644 \\
\hline $\mathrm{PDO}_{3}$ & 0.3696 & 0.0661 & 0.5192 & 0.6249 & 0.2471 & 0.1158 & 0.3261 \\
\hline $\mathrm{PDO}_{4}$ & 0.2361 & 0.268 & 0.1611 & 0.1356 & 0.0516 & 0.5546 & 0.4701 \\
\hline
\end{tabular}

Table 6. The overall priority weights and global score relative to $\mathrm{PDO}_{\mathrm{i}}$

\begin{tabular}{|c|c|c|c|c|c|c|}
\hline \multirow[t]{2}{*}{$\mathrm{PDO}_{\mathrm{i}}$} & \multicolumn{5}{|c|}{$\mathrm{W}_{\mathrm{GP}}$} & \multirow[t]{2}{*}{ GS } \\
\hline & $\mathrm{LCP}_{1}$ & $\mathrm{LCP}_{2}$ & $\mathrm{LCP}_{3}$ & $\mathrm{LCP}_{4}$ & $\mathrm{LCP}_{5}$ & \\
\hline $\mathrm{PDO}_{1}$ & 0.1704 & 0.379 & 0.1509 & 0.4294 & 0.3859 & 1.5158 \\
\hline $\mathrm{PDO}_{2}$ & 0.1411 & 0.1566 & 0.2837 & 0.1645 & 0.2454 & 0.9912 \\
\hline $\mathrm{PDO}_{3}$ & 0.2997 & 0.2155 & 0.2222 & 0.2331 & 0.1917 & 1.1622 \\
\hline $\mathrm{PDO}_{4}$ & 0.3886 & 0.2489 & 0.3432 & 0.173 & 0.177 & 1.3307 \\
\hline
\end{tabular}

According to Table 6, $\mathrm{PDO}_{1}$ has the highest score. This option is considered the most suitable for the design of the product since it generates the minimum environmental, economic, and social impacts through all the life cycle phases.

\section{Conclusion}

In this paper, we proposed a new model for the selection of the optimal sustainable design option. Our contribution is mainly observed through the integration of the environmental, economic, and the social aspects by using simplified assessment methods and by adding a multi-criteria decision making for the selection of a sustainable design option. In addition, we highlighted through the case study the extension of the ecodesign concept towards a sustainable design. In fact, we used the inventory data collected from similar previous designs of the batteries. These data are then classified and their relative impacts are evaluated by categories of indicators. The results showed that $\mathrm{PDO}_{1}$ is the optimal sustainable design option. This option generates the least impacts 
through the life cycle phases comparing to the remaining options. It consists of nontoxic materials and has low costs. $\mathrm{PDO}_{1}$ is considered safe for the consumer. Moreover, the experts confirmed the coherence of the obtained results with studies on similar batteries. However, it is important to note that these results depend on the time and space aspects due to the choice of the IMPACT2002+ method.

\section{References}

[1] G. Bruntland, "World commission on environment and development (WCED)," Our common future, 1987.

[2] I. 14062, "Environmental Management-Integrating Environmental Aspects into Product Design and Development.," 2002.

[3] D. C. Pigosso, H. Rozenfeld and T. C. McAloone, "Ecodesign maturity model: a management framework to support ecodesign implementation into manufacturing companies.," Journal of Cleaner Production, vol. 59, pp. 160$173,2013$.

[4] I. 14044, "Environmental Management--Life Cycle Assessment, Requirements and Guidelines," 2006.

[5] S. Neugebauer, S. Forin and M. Finkbeiner, "From Life Cycle Costing to Economic Life Cycle Assessment-Introducing an Economic Impact Pathway," Sustainability, vol. 8, p. 428, 2016.

[6] L. Dreyers, M. Hauschild and J. Schierbeck, "A Framework for Social Life Cycle Impact Assessment," International Journal of Life Cycle Assessment, vol. 11, pp. 88-97, 2006.

[7] T. L. Saaty, "Decision Making with Dependence and Feedback: The Analytic Network Process.," RWS Publications, Pittsburgh, 1996.

[8] L. Zadeh, "Fuzzy sets," Information and Control, vol. 8, pp. 338-353, 1965.

[9] L. Mikhailov and G. Madan, "Fuzzy analytic network process and its application to the development of decision support system," IEEE Transactions on Systems, Man, and Cybernetics-Part C: Application and Reviews, vol. 33, pp. 33-41, 2003.

[10] A. Romli, P. S. R. Prickett and S. Soe, "Integrated eco-design decisionmaking for sustainable product development.," International journal of production research, vol. 53, pp. 549-571, 2015.

[11] X. Wang, H. Chan and L. White, "A comprehensive decision support model for the evaluation of eco-designs," Journal of the Operational Research Society, vol. 65, pp. 917-934, 2014. 
[12] C. $\mathrm{Ng}$ and $\mathrm{K}$. Chuah, "A hybrid approach for environmental impact evaluation of design options.," International Journal of Sustainable Engineering, pp. 1-11, 2016.

[13] M. Fargnoli, M. De Minicis and M. Tronci, "Design management for sustainability: An integrated approach for the development of sustainable products.," Journal of Engineering and Technology Management, vol. 34, pp. 29-45, 2014.

[14] I. Bereketli and M. Genevois, "An integrated QFDE approach for identifying improvement strategies in sustainable product development," Journal of Cleaner Production, vol. 54, pp. 188-198, 2013.

[15] M. Younesi and E. Roghanian, "A framework for sustainable product design: a hybrid fuzzy approach based on Quality Function Deployment for Environment," Journal of Cleaner Production, vol. 108, pp. 385-394, 2015.

[16] B. Marques, A. Tadeu, J. De Brito and J. Almeida, "A Perspective On The Development Of Sustainable Construction Products: An Eco-design Approach.," Internaltional Journal of Sustainable Development and Planning , vol. 12, pp. 304-314, 2017.

[17] C. Ng and K. Chuah, "Evaluation of Design Alternatives' Environmental Performance Using AHP and ER Approaches.," IEEE Systems Journal, vol. 8, pp. 1185-1192, 2014.

[18] G. Wernet, C. Bauer, B. Steubing, J. Reinhard, E. Moreno-Ruiz and B. Weidema, "The ecoinvent database version 3 (part I): overview and methodology.," International Journal of Life Cycle Assessment, pp. 1-13, 2016.

[19] O. Jolliet, M. Margni, R. Charles, S. Humbert, J. Payet, G. Rebitzer and R. Rosenbaum, "IMPACT 2002+: a new life cycle impact assessment methodology," International Journal of Life Cycle Assessment, vol. 8, pp. 324330, 2003.

[20] S. Onut, S. Kara and E. Isik, "Long term supplier selection using a combined fuzzy MCDM approach: A case study for a telecommunication company," Expert Systems with Applications, vol. 36, pp. 3887-3895, 2009.

[21] B. Scrosati and J. Garche, "Lithium batteries: Status, prospects and future," Journal of Power Sources, vol. 195, pp. 2419-2430, 2010.

[22] C. H. Chen, J. Liu, M. E. Stoll, G. Henriksen, D. R. Vissers and K. Amine, "Aluminum-doped lithium nickel cobalt oxide electrodes for high-power lithium-ion batteries.," Journal of power Sources, vol. 128, pp. 278-285, 2004.

[23] M. M. Thackeray, C. S. Johnson, J. T. Vaughey, N. Li and S. A. Hackney, "Advances in manganese-oxide 'composite'electrodes for lithium-ion batteries," Journal of Materials Chemistry, vol. 15, pp. 2257-2267, 2005. 